\title{
Perancangan Sistem Optik DWDM 8 Kanal dengan Penguat EDFA
}

\section{The Design of 8 Channel DWDM Optical System by EDFA Amplifier}

\author{
Fauza Khair ${ }^{1, *}$, Amiludin ${ }^{2}$, Angga Pratama ${ }^{3}$, Fikri Nizar Gustiyana ${ }^{4}$, \\ Rizki Dwi Rahmawan ${ }^{5}$, Yudo Reza ${ }^{6}$ \\ ${ }^{1}$ Program Studi D3 Teknik Telekomunikasi, ${ }^{2,3,4,5,6}$ Program Studi S1 Teknik Telekomunikasi, \\ Fakultas Teknik Telekomunikasi dan Elektro, Institut Teknologi Telkom Purwokerto \\ Jl. D.I. Panjaitan No. 128, Purwokerto 53116, Jawa Tengah, Indonesia \\ $1, *$ Penulis korespondensi: fauza.khair@ittelkom-pwt.ac.id \\ 220101216@ittelkom-pwt.ac.id, ${ }^{3} 20101176 @$ ittelkom-pwt.ac.id, \\ 420101210@ittelkom-pwt.ac.id, ${ }^{5} 20101181 @$ ittelkom-pwt.ac.id, ${ }^{6}$ 20101211@ittelkom-pwt.ac.id
}

Received on 22-02-2021, accepted on 17-07-2021, published on 17-07-2021

\begin{abstract}
Abstrak
Penguat EDFA dibutuhkan untuk permasalahan komunikasi di Indonesia yang terbatas jarak dan waktu. EDFA merupakan penguat optik yang dibuat dengan cara mencampurkan ion erbium ke dalam serat optik. Supaya EDFA digunakan dengan efisien maka diperlukan penelitian performansi yang sesuai untuk bit rate tertentu Pada Tugas Besar kali ini, akan dilakukan pemodelan dan simulasi link DWDM menggunakan software Optisystem 17.0, kemudian akan dilakukan simulasi link DWDM dengan 2 penguat erbium doped fiber amplifier (EDFA) ditambah menggunakan Single mode Fiber dan Dispersion Compensation Fiber. EDFA dipilih karena EDFA dapat menguatkan sinyal optik tanpa mengubahnya menjadi sinyal elektrik terlebih dahulu. Pada Tugas besar ini, serat optik akan diatur panjangnya dengan panjang Dispersion Compensating Fiber tetap yaitu $10 \mathrm{Km}$. Panjang link yang digunakan yaitu $50 \mathrm{Km}, 60 \mathrm{Km}, 70 \mathrm{Km}, 80 \mathrm{Km}$ dan $90 \mathrm{Km}$, bitrate yang digunakan yaitu $10 \mathrm{Gbps}, 9 \mathrm{Gbps}, 8$ Gbps dan 7 Gbps, format modulasi yang digunakan yaitu NRZ. Selanjutnya, hasil dari simulasi akan dilihat nilai dari SNR, OSNR, Q faktor dan BER masing-masing skema EDFA, sehingga didapatkan nilai yang terbaik dari kelima jarak dan variasi bit rate yang digunakan. Dari hasil analisis yang dilakukan, penguat (EDFA) memiliki korelasi terhadap kinerja sistem DWDM ini, dimana didapatkan pada skema Bit rate 7 Gbps dan 8 Gbps dengan maksimal panjang fiber $100 \mathrm{Km}$ penggunaan penguat EDFA sangat berpengaruh pada kelayakan BER dan Q-Factor dan pada skema Bit Rate 9 Gbps dan 10 Gbps terdapat nilai BER dan Q-Factor yang tidak memenuhi standar kelayakan pada jarak tertentu.
\end{abstract}

Kata kunci: BER, Bit Rate, DWDM, EDFA, Q Factor.

\section{Abstract}

EDFA amplifier is needed to solve communication problems in Indonesia which are limited by distance and time. EDFA is an optical amplifier that mixes Erbium ions into the optical fiber. To be used efficiently, a specific bit rate of EDFA is needed to be researched appropriately. In this research, modeling and simulation of the DWDM link will be carried out using Optisystem 17.0 software. Then a simulation of the DWDM link will be carried out with two erbium-doped fiber amplifiers (EDFA) plus using Single-mode Fiber and Dispersion Compensation Fiber. EDFA can amplify optical signals without converting them into electrical signals. The optical fiber will be adjusted in length with a fixed Dispersion Compensating Fiber length of $10 \mathrm{Km}$. The link lengths were 50, 60, 70, 80, and 90 $\mathrm{Km}$. At the same time, the bitrate was $10,9,8$, and $7 \mathrm{Gbps}$. The modulation format was NRZ. Furthermore, the simulation results will see the value of SNR, OSNR, Q factor, and BER for each EDFA scheme so that the best value for the five distances and variations in bit rate is obtained. From the analysis results, the amplifier (EDFA) correlates with the performance of this DWDM system. These results were obtained in the Bitrate scheme of 7 and $8 \mathrm{Gbps}$ with a maximum fiber length of $100 \mathrm{Km}$. The EDFA amplifier significantly affects the feasibility of BER 
and Q-Factor and the scheme. Bit Rates of 9 and 10 Gbps have BER and Q-Factor values that do not meet the eligibility standards at a certain distance.

Keywords: BER, Bit Rate, DWDM, EDFA, Q Factor.

\section{Pendahuluan}

Perkembangan teknologi telekomunikasi sekarang ini mengalami kemajuan sangat cepat. Hal ini diakibatkan adanya permintaan dan peningkatan kebutuhan akan informasi, yang terus memacu para pengembang untuk memberikan suatu media transmisi yang dapat diandalkan dari segi kualitas sinyal, waktu akses ( no delay), keamanan data, serta daerah cakupan penerima yang luas[1-4]. Teknologi Dense Wavelength Division Multiplexing (DWDM merupakan teknik transmisi yang memanfaatkan cahaya dengan panjang gelombang yang berbeda - beda sebagai kanal-kanal informasi, sehingga setelah dilakukan proses multiplexing seluruh panjang gelombang tersebut dapat di transmisikan melalui suatu media serat optik, namun jarak transmisi antara Transmitter dan Receiver yang terlalu jauh sering kali membuat tingkatan daya sinyal pada sistem DWDM menurun, hal ini tentunya sangat merugikan karena adanya rugi-rugi sepanjang lintasan. Sehingga dibutuhkan sebuah optical amplifier untuk mengatasi hal tersebut, yang dikenal memiliki kemampuan untuk menguatkan daya sinyal yang mengalami pelemahan[2-4].

Jarak yang semakin jauh biasanya menimbulkan dispersi yang lebih banyak juga, hal ini dikarenakan redaman/loss yang terjadi di sepanjang serat optik semakin banyak. Redaman/loss yang terjadi disepanjang kabel optik bisa berpengaruh terhadap daya terima, BER, dan faktor kualitas dari suatu serat optik. Untuk mengatasi masalah dispersi ini biasanya pada komunikasi serat optik dipasang sebuah penguat EDFA. EDFA berfungsi untuk menguatkan sinyal optik tanpa mengubahnya ke sinyal elektrik terlebih dahulu, EDFA memiliki kelebihan seperti toleransi penguat serat teradap panjang gelombang sinyal relatif lebih besar.

Oleh karena itu, penelitian ini melakukan perancangan simulasi pada sistem transmisi Dense Wavelength Division Multiplexing (DWDM) pada jarak 60 - $100 \mathrm{~km}$ dengan menggunakan media transmisi Single Mode Fiber (SMF) + Dispersion dan optical amplifier jenis Erbium Doped Fiber Amplifier (EDFA). Tujuan dari penelitian ini adalah untuk mengetahui desain yang optimal untuk sistem transmisi DWDM pada jarak 60 - $100 \mathrm{~km}$ dengan membandingkan data hasil perhitungan dan data dari hasil simulasi.

Bersadarkan penelitian dari Sri Danaryani dengan judul "Studi Perancangan Jaringan Komunikasi Serat Optik DWDM L Band dengan Penguat Optikal Edfa”. Tujuan dari penelitian ini adalah melihat kapasitas transmisi dari DWDN dengan 4 nilai panjang gelombang sesuai dengan grid ITU-T 1568.77nm, $1569.59 \mathrm{~nm}, 1571,23 \mathrm{~nm}$ n 1.572,05 nm. Hasilnya dapat meminimalkan efek dari FWM mana harmonik yang dihasilkan tidak termasuk dalam panjang gelombang fundamental. Penggunaan EDFA dalam transmisi serat optik di DWDM shut sedang mempertimbangkan OSNR. Perhitungan OSNR tergantung pada jumlah panjang gelombang, bit rate, dispersi serat dan jumlah amplifier yang digunakan. Secara umum, semakin amplifier digunakan OSNR akan lebih kecil. bandwidth yang besar juga menurun OSNR. Jadi OSNR lebih kecil menunjukkan suara lebih dominan dibandingkan dengan sinyal[3].

Berdasarkan penelitian Dewiani Djamaluddin dengan judul "Analisis Penguat EDFA dan SOA pada Sistem Transmisi DWDM dengan Optisystem 14" penelitian ini perhitungan parameter power link budget dengan hasil simulasi, jarak maksimum transmisi sistem DWDM tanpa menggunakan penguat, perbandingan performansi penguatan antara EDFA dan SOA berdasarkan parameter Optical Signal to Noise Ratio (OSNR), dan Quality factor (Q factor), dan Bit Error Rate (BER). Pada perhitungan parameter link budget yang didasarkan pada tiga skema penempatan penguat didapatkan power penerima sebesar -17,6 dBm untuk booster - inline, -17,25 dBm untuk booster - pre amp, dan -14,18 dBm untuk inline - pre amp dengan sensitivitas penerima sebesar $-18 \mathrm{dBm}$. Dengan toleransi minimal BER sebesar 10-11, penggunaan penguat EDFA-EDFA pada skema booster - inline memiliki hasil BER paling baik yaitu 10-23 pada hasil perhitungan dan 10-19 10-32 pada hasil simulasi [2]. 


\section{Metode Penelitian}

\section{A. Digram Alir Penelitian}

Pada penelitian ini akan dilakukan beberapa tahap penelitian, yaitu tahap studi literatur, tahap perancangan skema sistem optik DWDM dengan penguat EDFA, tahap simulasi sistem, tahap analisis hasil simulasi dari sistem dan terakhir tahap kesimpulan. Tahap pertama yaitu studi literatur pada tahap ini dilakukan pengumpulan data yang dapat membantu proses pelaksanaan pada penelitian. Pengumpulan data berguna dalam pembuatan skema sistem optik DWDM ditambah penguat EDFA yang terdapat dalam software Optisystem 17.1. Diagram alur penelitian dapaat dilihat pada gambar 1.

Tahap pertama yaitu studi literatur pada tahap ini dilakukan pengumpulan data yang dapat membantu proses pelaksanaan pada penelitian ini. Pengumpulan data berguna dalam pembuatan skema sistem optik DWDM dengan penguat EDFA yang terdapat pada software Optisystem 17.1. Pada tahap ini pun dibutuhkan teori penunjang dan pendukung yang berhubungan dengan topik penelitian seperti paper dan jurnal. Hal ini betujuan untuk lebih mengetahui dan memahami secara teori dari sistem dan metode yang baerkaitan dengan penelitian ini. Tahap kedua yaitu melakukan perancangan skema sistem optik DWDM dengan penguat EDFA ke berbagai skenario didalamnya. Perancangan ini dibuat pada simulasi software OptiSystem 17.1.

Tahap ketiga yaitu simulasi sistem optik DWDM dengan penguat EDFA. Pada tahap ini menggunakan simulasi dengan software Optisystem 17.1. Penelitian ini menggunakan beberapa variasi bit error dan variasi panjang fiber SMF dengan nilai DCF konstan. Tahap selanjutnya yaitu analisis simulasi hasil, berupa Min BER, Q-Factor, SNR, OSNR, Channel Spectrum, dan Optical Power dari parameter yang telah diamati. Proses Analisis dapat diamati dengan membandingkan performansi berupa Min BER, QFactor, SNR, OSNR, Channel Spectrum, dan Optical Power dari variasi bit error dan panjang SMF yang beragam. Tahap terakhir dari penelitian ini yaitu kesimpulan dari analisis yang telah dilakukan. Kesimpulan didapatkan dari hasil pengamatan dan perbandingan Min BER, Q-Factor, SNR, OSNR, Channel Spectrum, dan Optical Power dari variasi bit error dan panjang SMF yang beragam.

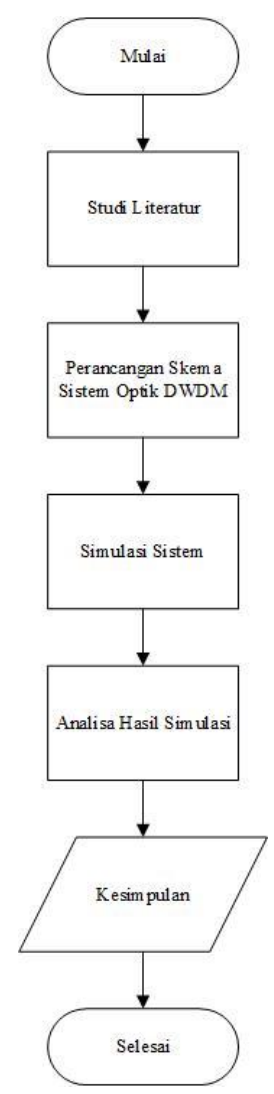

Gambar 1. Diagram Alir Penelitian 


\section{B. Blok Diagram Sistem}

Pada blok diagram sistem ini, dapat dijelaskan tentang sistem optik DWDM dengan tambahan penguat EDFA yang terdiri dari 8 channel transmitter, Mux, fiber optik (SMF), Penguat EDFA, fiber optik (DCF), Penguat EDFA, Demux dan 8 channel receiver seperti yang ada pada gambar 2

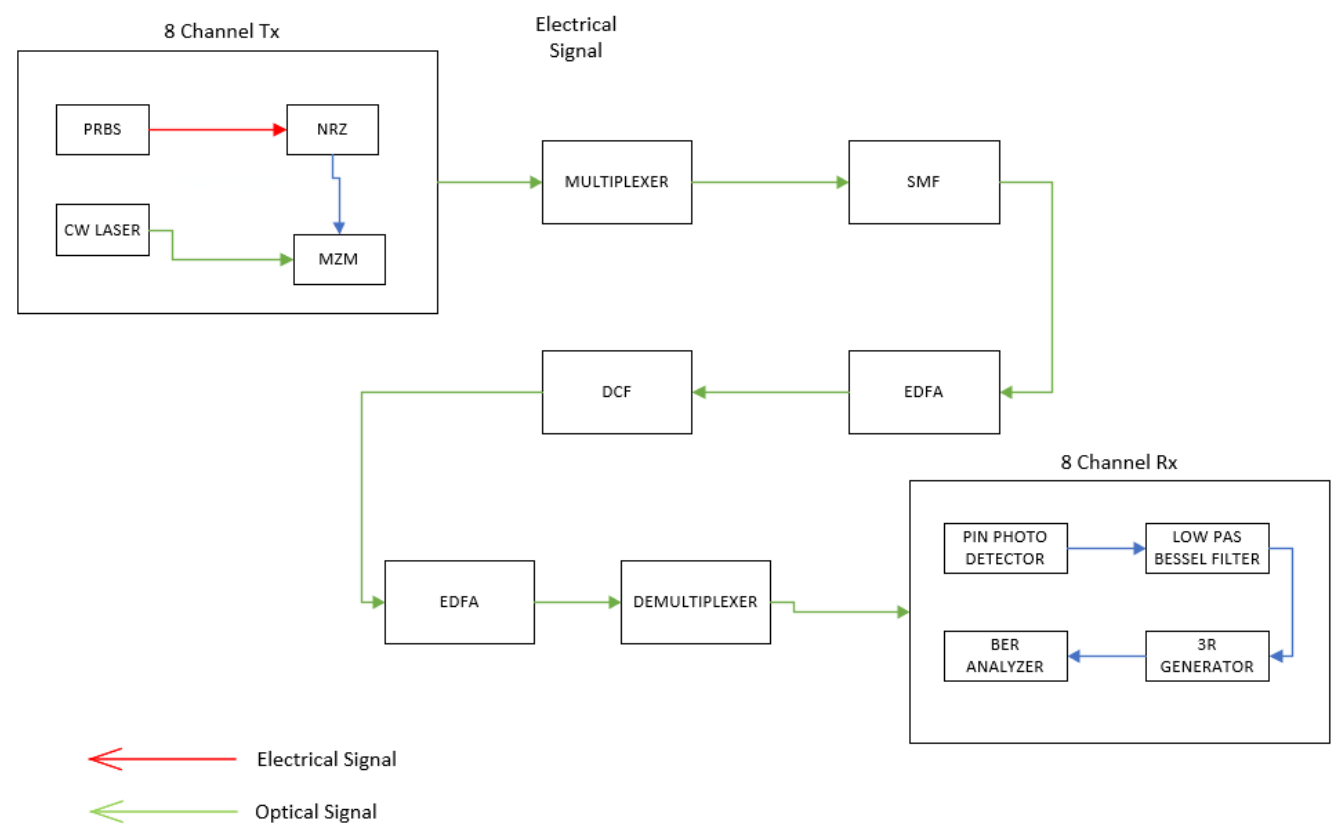

Gambar 2. Blok Diagram Sistem

\section{Parameter Simulasi}

Dalam pengerjaan simulasi dibutuhkan parameter-parameter yang digunakan dalam melakukan simulasi. Beberapa parameter yang digunakan dapat dilihat dari tabel 1:

Tabel 1 Parameter Simulasi

\begin{tabular}{|c|c|c|}
\hline Parameter & Nilai & Satuan \\
\hline BitRate & $7,8,9, \& 10$ & $\mathrm{Gbps}$ \\
\hline Time Window & $0.14628,0.128,0.113777, \& 0.1024$ & $\mu \mathrm{Hz}$ \\
\hline Sample Rate & $224,256,288, \& 320$ & $\mathrm{GHz}$ \\
\hline Sequence Length & 1024 & $\mathrm{Bits}$ \\
\hline Sample per Bit & 32 & \\
\hline Number of Samples & 32768 & \\
\hline Sensitivity & -100 & $\mathrm{dBm}$ \\
\hline Channel Spacing & 100 & $\mathrm{GHz}$ \\
\hline
\end{tabular}

Sumber optik yang digunakan dalam simulasi ini adalah CW laser. Terdapat parameter CW laser yang digunakan pada simulasi ini dapat dilihat pada tabel 2 sebagai berikut:

Tabel 2 Parameter CW Laser

\begin{tabular}{|l|c|c|}
\hline Parameter & Nilai & Satuan \\
\hline Frequency & $193.1,193.2,193.3,193.4,193.5,193.6,193.7,193.8$ & $\mathrm{THz}$ \\
\hline Power & 0 & $\mathrm{dBm}$ \\
\hline Linewidth & 10 & $\mathrm{MHz}$ \\
\hline
\end{tabular}


Penggunaan fiber optik yang dilakukan pada simulasi ini adalah fiber optik jenis single mode fiber (SMF) dan Dispersion Compensating Fiber (DCF). Parameter penggunaan fiber optik SMF dapat dilihat dari tabel 3 berikut ini:

Tabel 3 Parameter fiber optik SMF

\begin{tabular}{|l|c|c|}
\hline \multicolumn{1}{|c|}{ Parameter } & Nilai & Satuan \\
\hline Reference Wavelength & 1550 & $\mathrm{~nm}$ \\
\hline Length & $50,60,70,80, \& 90$ & $\mathrm{~km}$ \\
\hline Attenuation & 0.2 & $\mathrm{~dB} / \mathrm{km}$ \\
\hline Dispersion & 16.75 & $\mathrm{ps} / \mathrm{nm} / \mathrm{km}$ \\
\hline Dispersion Slope & 0.075 & $\mathrm{ps} / \mathrm{nm} 2 / \mathrm{km}$ \\
\hline
\end{tabular}

Sedangkan untuk parameter penggunaan fiber optik DCF dapat dilihat dari tabel 4 berikut ini:

Tabel 4 Parameter fiber optik DCF

\begin{tabular}{|l|c|c|}
\hline \multicolumn{1}{|c|}{ Parameter } & Nilai & Satuan \\
\hline Reference Wavelength & 1550 & $\mathrm{~nm}$ \\
\hline Length & 10 & $\mathrm{~km}$ \\
\hline Attenuation & 0.2 & $\mathrm{~dB} / \mathrm{km}$ \\
\hline Dispersion & 16.75 & $\mathrm{ps} / \mathrm{nm} / \mathrm{km}$ \\
\hline Dispersion Slope & 0.075 & $\mathrm{ps} / \mathrm{nm}^{2} / \mathrm{km}$ \\
\hline Effective Area & 80 & $\mathrm{Um}^{2}$ \\
\hline
\end{tabular}

Pada simulasi ini digunakan penguat optik untuk menjaga kualitas sinyal tetap stabil. Penguat optik yang digunakan adalah Erbiriun Doped Fiber Amplifier (EDFA). Parameter yang digunakan pada simulasi ini terdapat pada Tabel 5 berikut [5]:

Tabel 5 Parameter EDFA

\begin{tabular}{|l|c|c|}
\hline Parameter & Nilai & Satuan \\
\hline Gain & 20 & $\mathrm{~dB}$ \\
\hline Power & 10 & $\mathrm{dBm}$ \\
\hline Noise Figure & 4 & $\mathrm{~dB}$ \\
\hline
\end{tabular}

Penggunaan photodetektor pada simulasi ini adalah jenis photodetektor PIN (P intrinsic N). Parameter yang digunakan pada photodetector PIN dapat dilihat pada tebel 3.6 berikut ini:

Tabel 6 Parameter EDFA

\begin{tabular}{|l|c|c|}
\hline Parameter & Nilai & Satuan \\
\hline Responsitivity & 1 & $\mathrm{~A} / \mathrm{W}$ \\
\hline Dark Current & 10 & $\mathrm{nA}$ \\
\hline Frequency & $193.1,193.2,193.3,193.4,193.5,193.6,193.7,193.8$ & $\mathrm{THz}$ \\
\hline
\end{tabular}

\section{Hasil dan Pembahasan}

Pada bab ini menjelaskan tentang hasil simulasi dari sistem yang telah dirancang pada bab sebelumnya. Dalam bab ini dipaparkan tentang pengaruh variasi bit error dan panjang SMF pada sistem optik DWDM dengan penguat EDFA. 


\section{A. Hasil Rancangan Sistem Optik DWDM dengan Penguat EDFA}

Perancangan sistem DWDM dengan penguat EDFA dilakukan denga dengan variasi bit error dan panjang SMF sebagai skenario simulasi. Adapun hasil perancangan sistem optik DWDM dengan Penguat EDFA.

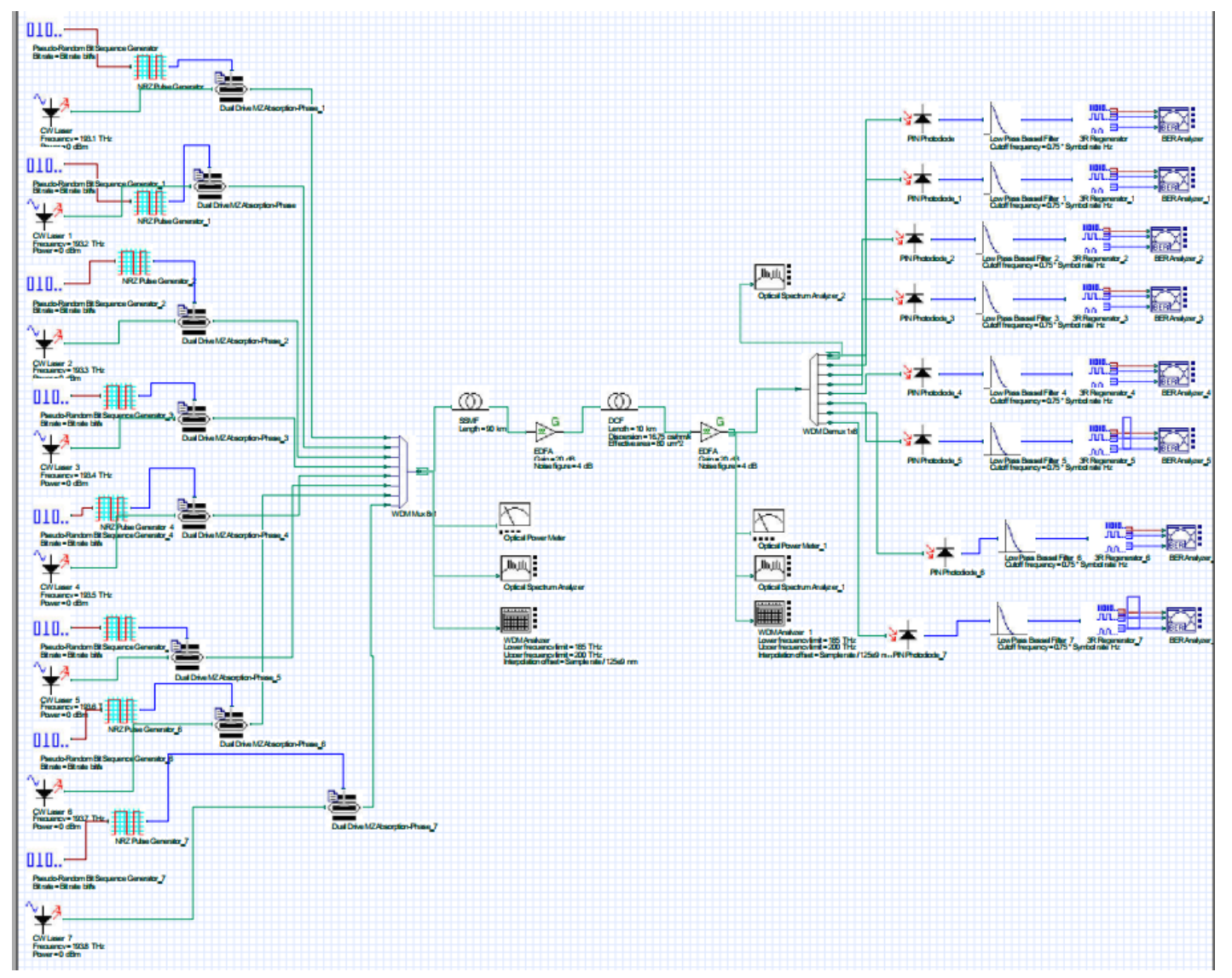

Gambar 3 Hasil Rancangan Sistem Optik DWDM dengan Penguat EDFA

\section{B. Hasil dan Pembahasan Simulasi}

Hasil dari penelitian yang telah dilakukan mencakup nilai Min BER, Q-factor SNR, OSNR, Channel Spectrum, dan Optical Power dari simulasi sistem optik DWDM dengan penguat EDFA. Ragam variasi bit rate dan variasi panjang fiber SMF dilakukan dengan bit rate sebesar 7 Gbps, 8 Gbps, 9 Gbps 10 Gbps dan panjang fiber SMF $50 \mathrm{~km}, 60 \mathrm{~km}, 70 \mathrm{~km}, 80 \mathrm{~km}, 90 \mathrm{~km}$. Penelitian ini juga menggunakan 8 Channel Tx dan 8 Channel Rx dengan frekuensi masing-masing channel $193.1 \mathrm{THz}, 193.2 \mathrm{THz}, 193.3 \mathrm{THz}, 193.4$ THz, 193.5 THz, 193.6 THz, 193.7 THz, 193.8 THz dengan penguatan EDFA sebesar $20 \mathrm{~dB}$.

Pada tabel 7(a)(b)(c)(d) menunjukkan hasil Min BER dari masing-masing channel dan tabel 8 menunjukan nilai rata-rata hasil Min BER dari simulasi yang dilakukan dengan variasi Bit rate dan ragam variasi panjang fiber SMF. Bit error rate (BER) merupakan laju kesalahan bit yang terjadi dalam mentransmisikan sinyal digital. Sensitivitas merupakan daya optik minimum dari sinyal yang datang pada bit error rate yang dibutuhkan. Dalam komunikasi serat optik, dibutuhkan BER yang dicapai minimal 10${ }^{9}[6]$. 
Tabel 7(a). Hasil Min BER pada Bit rate 7 Gbps

\begin{tabular}{|c|c|c|c|c|c|}
\hline \multirow{2}{*}{$\begin{array}{c}\text { Frequency } \\
(\mathrm{THz})\end{array}$} & \multicolumn{5}{|c|}{ Panjang Fiber SMF + DCF $(\mathrm{Km})$} \\
\cline { 2 - 6 } & 60 & 70 & 80 & 90 & 100 \\
\hline 193.1 & $1.59 \mathrm{E}-129$ & $5.97 \mathrm{E}-132$ & $3.56 \mathrm{E}-124$ & $2.67 \mathrm{E}-111$ & $1.68 \mathrm{E}-89$ \\
\hline 193.2 & $1.33 \mathrm{E}-112$ & $5.83 \mathrm{E}-127$ & $9.70 \mathrm{E}-111$ & $1.97 \mathrm{E}-112$ & $1.61 \mathrm{E}-93$ \\
\hline 193.3 & $1.52 \mathrm{E}-139$ & $6.54 \mathrm{E}-135$ & $9.89 \mathrm{E}-125$ & $3.40 \mathrm{E}-103$ & $4.96 \mathrm{E}-97$ \\
\hline 193.4 & $2.89 \mathrm{E}-127$ & $8.98 \mathrm{E}-141$ & $4.39 \mathrm{E}-131$ & $1.21 \mathrm{E}-122$ & $1.74 \mathrm{E}-93$ \\
\hline 193.5 & $3.23 \mathrm{E}-122$ & $4.82 \mathrm{E}-116$ & $4.77 \mathrm{E}-115$ & $3.56 \mathrm{E}-102$ & $2.68 \mathrm{E}-91$ \\
\hline 193.6 & $1.02 \mathrm{E}-132$ & $4.41 \mathrm{E}-125$ & $1.64 \mathrm{E}-118$ & $7.67 \mathrm{E}-117$ & $2.67 \mathrm{E}-93$ \\
\hline 193.7 & $7.71 \mathrm{E}-119$ & $3.60 \mathrm{E}-134$ & $5.90 \mathrm{E}-123$ & $7.52 \mathrm{E}-104$ & $1.42 \mathrm{E}-94$ \\
\hline 193.8 & $4.62 \mathrm{E}-111$ & $3.17 \mathrm{E}-106$ & $1.42 \mathrm{E}-129$ & $6.32 \mathrm{E}-112$ & $1.38 \mathrm{E}-101$ \\
\hline
\end{tabular}

Tabel 7(b). Hasil Min BER pada Bit rate 8 Gbps

\begin{tabular}{|c|c|c|c|c|c|}
\hline \multirow{2}{*}{$\begin{array}{c}\text { Frequency } \\
(\mathrm{THz})\end{array}$} & \multicolumn{5}{|c|}{ Bit Rate 8 Gbps } \\
\cline { 2 - 6 } & 60 & 70 & 80 & 90 & 100 \\
\hline 193.1 & $1.25 \mathrm{E}-32$ & $3.98 \mathrm{E}-32$ & $5.76 \mathrm{E}-31$ & $2.60 \mathrm{E}-26$ & $4.90 \mathrm{E}-19$ \\
\hline 193.2 & $2.86 \mathrm{E}-33$ & $7.15 \mathrm{E}-32$ & $1.88 \mathrm{E}-30$ & $3.82 \mathrm{E}-22$ & $2.59 \mathrm{E}-23$ \\
\hline 193.3 & $6.31 \mathrm{E}-35$ & $3.72 \mathrm{E}-33$ & $3.73 \mathrm{E}-30$ & $3.97 \mathrm{E}-27$ & $1.65 \mathrm{E}-24$ \\
\hline 193.4 & $1.67 \mathrm{E}-34$ & $1.42 \mathrm{E}-34$ & $6.21 \mathrm{E}-30$ & $1.08 \mathrm{E}-29$ & $9.61 \mathrm{E}-23$ \\
\hline 193.5 & $3.87 \mathrm{E}-33$ & $3.56 \mathrm{E}-32$ & $3.18 \mathrm{E}-34$ & $3.14 \mathrm{E}-27$ & $1.25 \mathrm{E}-19$ \\
\hline 193.6 & $2.75 \mathrm{E}-33$ & $2.02 \mathrm{E}-33$ & $8.77 \mathrm{E}-30$ & $1.13 \mathrm{E}-30$ & $1.56 \mathrm{E}-23$ \\
\hline 193.7 & $5.50 \mathrm{E}-33$ & $1.77 \mathrm{E}-32$ & $2.38 \mathrm{E}-31$ & $2.36 \mathrm{E}-27$ & $4.93 \mathrm{E}-24$ \\
\hline 193.8 & $8.71 \mathrm{E}-35$ & $2.67 \mathrm{E}-34$ & $8.75 \mathrm{E}-31$ & $2.41 \mathrm{E}-29$ & $4.51 \mathrm{E}-21$ \\
\hline
\end{tabular}

Tabel 7(c). Hasil Min BER pada Bit rate 9 Gbps

\begin{tabular}{|c|c|c|c|c|c|}
\hline \multirow{2}{*}{$\begin{array}{c}\text { Frequency } \\
(\mathrm{THz})\end{array}$} & \multicolumn{5}{|c|}{ Panjang Fiber SMF + DCF $(\mathrm{Km})$} \\
\cline { 2 - 6 } & 60 & 70 & 80 & 90 & 100 \\
\hline 193.1 & $7.64 \mathrm{E}-14$ & $5.94 \mathrm{E}-13$ & $4.48 \mathrm{E}-12$ & $6.15 \mathrm{E}-11$ & $3.22 \mathrm{E}-09$ \\
\hline 193.2 & $1.17 \mathrm{E}-13$ & $6.30 \mathrm{E}-13$ & $2.03 \mathrm{E}-12$ & $1.68 \mathrm{E}-10$ & $3.57 \mathrm{E}-09$ \\
\hline 193.3 & $7.77 \mathrm{E}-14$ & $3.20 \mathrm{E}-13$ & $2.73 \mathrm{E}-12$ & $6.06 \mathrm{E}-11$ & $2.73 \mathrm{E}-09$ \\
\hline 193.4 & $6.42 \mathrm{E}-14$ & $3.10 \mathrm{E}-13$ & $4.08 \mathrm{E}-11$ & $9.28 \mathrm{E}-11$ & $1.98 \mathrm{E}-09$ \\
\hline 193.5 & $6.85 \mathrm{E}-14$ & $5.36 \mathrm{E}-13$ & $4.66 \mathrm{E}-12$ & $1.13 \mathrm{E}-10$ & $2.26 \mathrm{E}-09$ \\
\hline 193.6 & $4.21 \mathrm{E}-14$ & $6.29 \mathrm{E}-13$ & $3.86 \mathrm{E}-12$ & $5.46 \mathrm{E}-11$ & $1.94 \mathrm{E}-09$ \\
\hline 193.7 & $9.87 \mathrm{E}-14$ & $2.21 \mathrm{E}-13$ & $1.69 \mathrm{E}-12$ & $8.49 \mathrm{E}-11$ & $1.35 \mathrm{E}-09$ \\
\hline 193.8 & $4.87 \mathrm{E}-14$ & $3.01 \mathrm{E}-13$ & $7.53 \mathrm{E}-12$ & $2.01 \mathrm{E}-11$ & $1.87 \mathrm{E}-09$ \\
\hline
\end{tabular}

Tabel 7(d). Hasil Min BER pada Bit rate $10 \mathrm{Gbps}$

\begin{tabular}{|c|c|c|c|c|c|}
\hline \multirow{2}{*}{$\begin{array}{c}\text { Frequency } \\
(\text { THz })\end{array}$} & \multicolumn{5}{|c|}{ Panjang Fiber SMF + DCF $(\mathrm{Km})$} \\
\cline { 2 - 6 } & 60 & 70 & 80 & 90 & 100 \\
\hline 193.1 & $3.47 \mathrm{E}-07$ & $4.12 \mathrm{E}-07$ & $2.47 \mathrm{E}-06$ & $1.65 \mathrm{E}-05$ & $2.01 \mathrm{E}-02$ \\
\hline 193.2 & $1.37 \mathrm{E}-07$ & $4.56 \mathrm{E}-07$ & $2.16 \mathrm{E}-06$ & $1.39 \mathrm{E}-05$ & $4.37 \mathrm{E}-02$ \\
\hline 193.3 & $1.21 \mathrm{E}-07$ & $4.29 \mathrm{E}-07$ & $1.88 \mathrm{E}-06$ & $1.21 \mathrm{E}-05$ & $4.13 \mathrm{E}-02$ \\
\hline 193.4 & $6.12 \mathrm{E}-08$ & $2.31 \mathrm{E}-07$ & $2.75 \mathrm{E}-06$ & $1.38 \mathrm{E}-05$ & $3.99 \mathrm{E}-02$ \\
\hline 193.5 & $1.58 \mathrm{E}-07$ & $4.81 \mathrm{E}-07$ & $1.99 \mathrm{E}-06$ & $8.38 \mathrm{E}-06$ & $5.55 \mathrm{E}-05$ \\
\hline 193.6 & $1.39 \mathrm{E}-07$ & $5.05 \mathrm{E}-07$ & $1.91 \mathrm{E}-06$ & $8.23 \mathrm{E}-06$ & $4.09 \mathrm{E}-05$ \\
\hline 193.7 & $1.48 \mathrm{E}-07$ & $4.56 \mathrm{E}-07$ & $2.03 \mathrm{E}-06$ & $7.01 \mathrm{E}-06$ & $2.63 \mathrm{E}-02$ \\
\hline 193.8 & $1.32 \mathrm{E}-07$ & $4.68 \mathrm{E}-07$ & $3.30 \mathrm{E}-06$ & $9.76 \mathrm{E}-06$ & $4.42 \mathrm{E}-05$ \\
\hline
\end{tabular}


Tabel 8. Hasil rata - rata Min BER

\begin{tabular}{|c|c|c|c|c|c|c|}
\hline Jumlah & Bit Rate & \multicolumn{5}{|c|}{ Panjang Fiber SMF + DCF (Km) } \\
\cline { 3 - 7 } Kanal & $(\mathrm{Gbps})$ & 60 & 70 & 80 & 90 & 100 \\
\hline \multirow{4}{*}{8} & $7 \mathrm{Gbps}$ & $5.95 \mathrm{E}-112$ & $3.959 \mathrm{E}-107$ & $1.21 \mathrm{E}-111$ & $4.966 \mathrm{E}-103$ & $2.1352 \mathrm{E}-90$ \\
\cline { 2 - 7 } & $8 \mathrm{Gbps}$ & $3.4758 \mathrm{E}-33$ & $2.1343 \mathrm{E}-32$ & $2.784 \mathrm{E}-30$ & $4.779 \mathrm{E}-23$ & $7.7515 \mathrm{E}-20$ \\
\cline { 2 - 7 } & $9 \mathrm{Gbps}$ & $7.4113 \mathrm{E}-14$ & $4.4252 \mathrm{E}-13$ & $8.469 \mathrm{E}-12$ & $8.1949 \mathrm{E}-11$ & $2.3648 \mathrm{E}-09$ \\
\cline { 2 - 7 } & $10 \mathrm{Gbps}$ & $1.55 \mathrm{E}-07$ & $4.2955 \mathrm{E}-07$ & $2.311 \mathrm{E}-06$ & $1.1212 \mathrm{E}-05$ & 0.02143543 \\
\hline
\end{tabular}

Pada tabel 9(a)(b)(c)(d) menunjukkan hasil Q-Factor dari masing-masing channel dan tabel 10 menunjukkan hasil rata-rata nilai Q-Factor dari simulasi yang dilakukan. Nilai Q-Factor yang bekerja dengan baik dan sesuai standar adalah minimal bernilai 6 .

Tabel 9(a). Hasil Q-Factor pada Bit rate 7 Gbps

\begin{tabular}{|c|c|c|c|c|c|}
\hline \multirow{2}{*}{$\begin{array}{c}\text { Frequency } \\
(\mathrm{THz})\end{array}$} & \multicolumn{5}{|c|}{ Banjang Fiber SMF + DCF (Km) } \\
\cline { 2 - 6 } & 60 & 70 & 80 & 90 & 100 \\
\hline 193.1 & 24.171 & 24.4017 & 23.6591 & 22.3749 & 20.0122 \\
\hline 193.2 & 22.5051 & 23.9272 & 22.3171 & 22.4909 & 20.4687 \\
\hline 193.3 & 25.1087 & 24.6796 & 23.7132 & 21.5264 & 20.8584 \\
\hline 193.4 & 23.9575 & 25.2195 & 24.322 & 23.5112 & 20.4652 \\
\hline 193.5 & 23.4678 & 22.8561 & 22.755 & 21.4162 & 20.2173 \\
\hline 193.6 & 24.4742 & 23.7476 & 23.1024 & 22.937 & 20.4435 \\
\hline 193.7 & 23.1325 & 24.6111 & 23.5406 & 21.5958 & 20.5868 \\
\hline 193.8 & 22.3472 & 21.845 & 24.1785 & 22.4381 & 21.5342 \\
\hline
\end{tabular}

Tabel 9(b). Hasil Q-Factor pada Bit rate 8 Gbps

\begin{tabular}{|c|c|c|c|c|c|}
\hline \multirow{2}{*}{$\begin{array}{c}\text { Frequency } \\
(\mathrm{THz})\end{array}$} & \multicolumn{5}{|c|}{ Bit Rate 8 Gbps } \\
\cline { 2 - 6 } & 60 & 70 & 80 & 90 & 100 \\
\hline 193.1 & 11.8139 & 11.717 & 11.4925 & 10.5284 & 8.82696 \\
\hline 193.2 & 11.9378 & 11.6682 & 11.3873 & 9.59601 & 9.8595 \\
\hline 193.3 & 12.2517 & 11.9181 & 11.3297 & 10.7024 & 10.1335 \\
\hline 193.4 & 12.1709 & 12.1857 & 11.2832 & 11.2383 & 9.72678 \\
\hline 193.5 & 11.9129 & 11.7277 & 12.1235 & 10.7257 & 8.97908 \\
\hline 193.6 & 11.9414 & 11.9685 & 11.2536 & 11.4345 & 9.90906 \\
\hline 193.7 & 11.8824 & 11.785 & 11.5676 & 10.7509 & 10.025 \\
\hline 193.8 & 12.2251 & 12.1349 & 11.4556 & 11.1659 & 9.33745 \\
\hline
\end{tabular}

Tabel 9(c). Hasil Q-Factor pada Bit rate 9 Gbps

\begin{tabular}{|c|c|c|c|c|c|}
\hline \multirow{2}{*}{$\begin{array}{c}\text { Frequency } \\
(\mathrm{THz})\end{array}$} & \multicolumn{5}{|c|}{ Pit Rate 9 Gbps } \\
\cline { 2 - 6 } & 60 & 70 & 80 & 90 & 100 \\
\hline 193.1 & 7.35951 & 7.08254 & 6.797 & 6.41353 & 5.78335 \\
\hline 193.2 & 7.30061 & 7.07261 & 6.91193 & 6.25768 & 5.766 \\
\hline 193.3 & 7.35577 & 7.16553 & 6.86903 & 6.41489 & 5.81125 \\
\hline 193.4 & 7.38192 & 7.17206 & 6.48013 & 6.34788 & 5.86421 \\
\hline 193.5 & 7.37192 & 7.09426 & 6.79248 & 6.31962 & 5.84069 \\
\hline 193.6 & 7.43711 & 7.07299 & 6.81996 & 6.43205 & 5.869 \\
\hline 193.7 & 7.32349 & 7.21656 & 6.93773 & 6.36108 & 5.92616 \\
\hline 193.8 & 7.4181 & 7.17476 & 6.72238 & 6.58108 & 5.86897 \\
\hline
\end{tabular}


Tabel 9(d). Hasil Q-Factor pada Bit rate $10 \mathrm{Gbps}$

\begin{tabular}{|c|c|c|c|c|c|}
\hline \multirow{2}{*}{$\begin{array}{c}\text { Frequency } \\
(\mathrm{THz})\end{array}$} & \multicolumn{5}{|c|}{ Panjang Fiber SMF + DCF $(\mathrm{Km})$} \\
\cline { 2 - 6 } & 60 & 70 & 80 & 90 & 100 \\
\hline 193.1 & 4.94065 & 4.90197 & 4.54123 & 4.12738 & 2.02133 \\
\hline 193.2 & 5.11049 & 4.88186 & 4.56713 & 4.16646 & 1.67735 \\
\hline 193.3 & 5.13368 & 4.89402 & 4.59939 & 4.19665 & 1.69781 \\
\hline 193.4 & 5.26187 & 5.01416 & 4.52142 & 4.16461 & 1.72373 \\
\hline 193.5 & 5.08085 & 4.86807 & 4.58533 & 4.28083 & 3.83962 \\
\hline 193.6 & 5.10911 & 4.86221 & 4.59317 & 4.28488 & 3.91242 \\
\hline 193.7 & 5.09829 & 4.88283 & 4.5793 & 4.31744 & 1.90644 \\
\hline 193.8 & 5.11698 & 4.87464 & 4.48379 & 4.24431 & 3.89487 \\
\hline
\end{tabular}

Tabel 10. Hasil rata-rata $Q$-Factor

\begin{tabular}{|c|c|c|c|c|c|c|}
\hline Jumlah & Bit Rate & \multicolumn{5}{|c|}{ Panjang Fiber SMF + DCF (Km) } \\
\cline { 3 - 7 } Kanal & $(\mathrm{Gbps})$ & 60 & 70 & 80 & 90 & 100 \\
\hline \multirow{4}{*}{8} & $7 \mathrm{Gbps}$ & 23.6455 & 23.910975 & 23.448488 & 22.2863125 & 20.5732875 \\
\cline { 2 - 7 } & $8 \mathrm{Gbps}$ & 12.017013 & 11.888138 & 11.486625 & 10.7677638 & 9.59966625 \\
\cline { 2 - 7 } & $9 \mathrm{Gbps}$ & 7.3685538 & 7.1314138 & 6.79133 & 6.39097625 & 5.84120375 \\
\cline { 2 - 7 } & $10 \mathrm{Gbps}$ & 5.10649 & 4.89747 & 4.558845 & 4.22282 & 2.58419625 \\
\hline
\end{tabular}

Pada Tabel 9(a)(b)(c)(d) menunjukkan hasil SNR dari masing-masing channel dan tabel XII menunjukkan nilai rata-rata hasil SNR dari simulasi yang dilakukan. Nilai SNR yang direkomendasikan adalah $25 \mathrm{~dB}$.

Tabel 11(a) Hasil SNR pada Bit rate 7 Gbps

\begin{tabular}{|c|c|c|c|c|c|}
\hline \multirow{2}{*}{$\begin{array}{c}\text { Frequency } \\
(\mathrm{THz})\end{array}$} & \multicolumn{5}{|c|}{ Bit Rate 7 Gbps } \\
\cline { 2 - 6 } & 60 & 70 & 80 & 90 & 100 \\
\hline 193.1 & $37.491173 \mathrm{~dB}$ & $35.7492 \mathrm{~dB}$ & $33.819942 \mathrm{~dB}$ & $31.907267 \mathrm{~dB}$ & $30.048955 \mathrm{~dB}$ \\
\hline 193.2 & $37.504234 \mathrm{~dB}$ & $35.706472 \mathrm{~dB}$ & $33.926011 \mathrm{~dB}$ & $31.970567 \mathrm{~dB}$ & $30.06401 \mathrm{~dB}$ \\
\hline 193.3 & $36.797004 \mathrm{~dB}$ & $35.30558 \mathrm{~dB}$ & $33.603681 \mathrm{~dB}$ & $31.737409 \mathrm{~dB}$ & $29.809102 \mathrm{~dB}$ \\
\hline 193.4 & $36.884697 \mathrm{~dB}$ & $35.333204 \mathrm{~dB}$ & $33.556234 \mathrm{~dB}$ & $31.775054 \mathrm{~dB}$ & $29.901611 \mathrm{~dB}$ \\
\hline 193.5 & $36.81225 \mathrm{~dB}$ & $35.27303 \mathrm{~dB}$ & $33.609453 \mathrm{~dB}$ & $31.756718 \mathrm{~dB}$ & $29.86405 \mathrm{~dB}$ \\
\hline 193.6 & $36.8435 \mathrm{~dB}$ & $35.362793 \mathrm{~dB}$ & $33.585353 \mathrm{~dB}$ & $31.80298 \mathrm{~dB}$ & $29.833355 \mathrm{~dB}$ \\
\hline 193.7 & $37.376179 \mathrm{~dB}$ & $35.700765 \mathrm{~dB}$ & $34.013381 \mathrm{~dB}$ & $31.983457 \mathrm{~dB}$ & $30.048837 \mathrm{~dB}$ \\
\hline 193.8 & $37.449983 \mathrm{~dB}$ & $35.701879 \mathrm{~dB}$ & $33.855636 \mathrm{~dB}$ & $31.90099 \mathrm{~dB}$ & $30.005259 \mathrm{~dB}$ \\
\hline
\end{tabular}

Tabel 11(b) Hasil SNR pada Bit rate 8 Gbps

\begin{tabular}{|c|c|c|c|c|c|}
\hline \multirow{2}{*}{$\begin{array}{c}\text { Frequency } \\
(\mathrm{THz})\end{array}$} & \multicolumn{5}{|c|}{ Bit Rate 8 Gbps } \\
\cline { 2 - 6 } & 60 & 70 & 80 & 90 & 100 \\
\hline & $38.031055 \mathrm{~dB}$ & $36.039922 \mathrm{~dB}$ & $34.042217 \mathrm{~dB}$ & $32.056546 \mathrm{~dB}$ & $30.0741 \mathrm{~dB}$ \\
\hline 193.1 & $38.159928 \mathrm{~dB}$ & $36.150515 \mathrm{~dB}$ & $33.972793 \mathrm{~dB}$ & $32.019147 \mathrm{~dB}$ & $30.102567 \mathrm{~dB}$ \\
\hline 193.2 & $38.061316 \mathrm{~dB}$ & $36.074814 \mathrm{~dB}$ & $34.111317 \mathrm{~dB}$ & $32.013427 \mathrm{~dB}$ & $30.078452 \mathrm{~dB}$ \\
\hline 193.3 & $38.062939 \mathrm{~dB}$ & $36.068588 \mathrm{~dB}$ & $34.055023 \mathrm{~dB}$ & $32.063871 \mathrm{~dB}$ & $30.118871 \mathrm{~dB}$ \\
\hline 193.4 & $38.019954 \mathrm{~dB}$ & $36.039850 \mathrm{~dB}$ & $33.993078 \mathrm{~dB}$ & $32.079468 \mathrm{~dB}$ & $30.064217 \mathrm{~dB}$ \\
\hline 193.6 & $38.030661 \mathrm{~dB}$ & $36.026009 \mathrm{~dB}$ & $34.099174 \mathrm{~dB}$ & $32.094249 \mathrm{~dB}$ & $29.929939 \mathrm{~dB}$ \\
\hline 193.7 & $38.017577 \mathrm{~dB}$ & $36.027443 \mathrm{~dB}$ & $34.060351 \mathrm{~dB}$ & $32.108545 \mathrm{~dB}$ & $30.058958 \mathrm{~dB}$ \\
\hline 193.8 & $38.157483 \mathrm{~dB}$ & $36.171891 \mathrm{~dB}$ & $34.047985 \mathrm{~dB}$ & $32.020772 \mathrm{~dB}$ & $30.09416 \mathrm{~dB}$ \\
\hline
\end{tabular}


Tabel 11(c) Hasil SNR pada Bit rate 9 Gbps

\begin{tabular}{|c|c|c|c|c|c|}
\hline \multirow{3}{*}{$\begin{array}{c}\text { Frequency } \\
\text { (THz) }\end{array}$} & \multicolumn{5}{|c|}{ Bit Rate 9 Gbps } \\
\hline & \multicolumn{5}{|c|}{ Panjang Fiber SMF + DCF $(\mathrm{Km})$} \\
\hline & 60 & 70 & 80 & 90 & 100 \\
\hline 193.1 & $15.473188 \mathrm{~dB}$ & $15.514027 \mathrm{~dB}$ & $15.466574 \mathrm{~dB}$ & $15.531805 \mathrm{~dB}$ & $15.458389 \mathrm{~dB}$ \\
\hline 193.2 & $15.4408 \mathrm{~dB}$ & $15.503277 \mathrm{~dB}$ & $15.609265 \mathrm{~dB}$ & $15.675269 \mathrm{~dB}$ & $15.400048 \mathrm{~dB}$ \\
\hline 193.3 & $15.491026 \mathrm{~dB}$ & $15.55987 \mathrm{~dB}$ & $15.497162 \mathrm{~dB}$ & $15.486149 \mathrm{~dB}$ & $15.577629 \mathrm{~dB}$ \\
\hline 193.4 & $12.35754 \mathrm{~dB}$ & $12.421173 \mathrm{~dB}$ & $12.493016 \mathrm{~dB}$ & $12.492232 \mathrm{~dB}$ & $12.416225 \mathrm{~dB}$ \\
\hline 193.5 & $12.267231 \mathrm{~dB}$ & $12.370508 \mathrm{~dB}$ & $12.512116 \mathrm{~dB}$ & $12.508942 \mathrm{~dB}$ & $12.335531 \mathrm{~dB}$ \\
\hline 193.6 & $15.532503 \mathrm{~dB}$ & $15.624921 \mathrm{~dB}$ & $15.50819 \mathrm{~dB}$ & $15.557208 \mathrm{~dB}$ & $15.498821 \mathrm{~dB}$ \\
\hline 193.7 & $15.543359 \mathrm{~dB}$ & $15.60362 \mathrm{~dB}$ & $15.580528 \mathrm{~dB}$ & $15.489176 \mathrm{~dB}$ & $15.592931 \mathrm{~dB}$ \\
\hline 193.8 & $15.521717 \mathrm{~dB}$ & $15.579472 \mathrm{~dB}$ & $15.580664 \mathrm{~dB}$ & $15.519673 \mathrm{~dB}$ & $15.422649 \mathrm{~dB}$ \\
\hline
\end{tabular}

Tabel 11(d) Hasil SNR pada Bit rate 10 Gbps

\begin{tabular}{|c|c|c|c|c|c|}
\hline \multirow{3}{*}{$\begin{array}{c}\text { Frequency } \\
(\mathrm{THz})\end{array}$} & \multicolumn{5}{|c|}{ Bit Rate $10 \mathrm{Gbps}$} \\
\hline & \multicolumn{5}{|c|}{ Panjang Fiber SMF + DCF $(\mathrm{Km})$} \\
\hline & 60 & 70 & 80 & 90 & 100 \\
\hline 193.1 & $35.358621 \mathrm{~dB}$ & $34.147089 \mathrm{~dB}$ & $32.583281 \mathrm{~dB}$ & $31.010359 \mathrm{~dB}$ & $29.295164 \mathrm{~dB}$ \\
\hline 193.2 & $35.223698 \mathrm{~dB}$ & $34.095211 \mathrm{~dB}$ & $32.670664 \mathrm{~dB}$ & $31.181863 \mathrm{~dB}$ & $29.378369 \mathrm{~dB}$ \\
\hline 193.3 & $35.23134 \mathrm{~dB}$ & $34.151699 \mathrm{~dB}$ & $32.689556 \mathrm{~dB}$ & $31.144858 \mathrm{~dB}$ & $29.401524 \mathrm{~dB}$ \\
\hline 193.4 & $33.57674 \mathrm{~dB}$ & $32.888699 \mathrm{~dB}$ & $31.802312 \mathrm{~dB}$ & $30.335188 \mathrm{~dB}$ & $28.981562 \mathrm{~dB}$ \\
\hline 193.5 & $33.262205 \mathrm{~dB}$ & $32.691876 \mathrm{~dB}$ & $31.825748 \mathrm{~dB}$ & $30.527894 \mathrm{~dB}$ & $28.95584 \mathrm{~dB}$ \\
\hline 193.6 & $35.182867 \mathrm{~dB}$ & $34.23149 \mathrm{~dB}$ & $32.762965 \mathrm{~dB}$ & $31.085106 \mathrm{~dB}$ & $29.355816 \mathrm{~dB}$ \\
\hline 193.7 & $35.138827 \mathrm{~dB}$ & $34.11527 \mathrm{~dB}$ & $32.64133 \mathrm{~dB}$ & $31.096268 \mathrm{~dB}$ & $29.446835 \mathrm{~dB}$ \\
\hline 193.8 & $35.054836 \mathrm{~dB}$ & $33.92227 \mathrm{~dB}$ & $32.699533 \mathrm{~dB}$ & $31.086968 \mathrm{~dB}$ & $29.372274 \mathrm{~dB}$ \\
\hline
\end{tabular}

Tabel 12 Hasil rata-rata $S N R$

\begin{tabular}{|c|c|c|c|c|c|c|}
\hline Jumlah & Bit Rate & \multicolumn{5}{|c|}{ Panjang Fiber SMF + DCF (Km) } \\
\cline { 3 - 7 } Kanal & $($ Gbps $)$ & 60 & 70 & 80 & 90 & 100 \\
\hline \multirow{4}{*}{8} & 7 & $37.1448775 \mathrm{~dB}$ & $35.5166154 \mathrm{~dB}$ & $33.746211 \mathrm{~dB}$ & $31.8543053 \mathrm{~dB}$ & $29.9468974 \mathrm{~dB}$ \\
\cline { 2 - 7 } & 8 & $38.0676141 \mathrm{~dB}$ & $36.074879 \mathrm{~dB}$ & $34.047742 \mathrm{~dB}$ & $32.0570031 \mathrm{~dB}$ & $30.065158 \mathrm{~dB}$ \\
\cline { 2 - 7 } & 9 & $14.7034205 \mathrm{~dB}$ & $14.7721085 \mathrm{~dB}$ & $14.780939 \mathrm{~dB}$ & $14.7825568 \mathrm{~dB}$ & $14.7127779 \mathrm{~dB}$ \\
\cline { 2 - 7 } & 10 & $37.1448775 \mathrm{~dB}$ & $35.5166154 \mathrm{~dB}$ & $33.746211 \mathrm{~dB}$ & $31.8543053 \mathrm{~dB}$ & $29.9468974 \mathrm{~dB}$ \\
\hline
\end{tabular}

Pada tabel 13(a)(b)(c)(d) menunjukkan hasil OSNR dari masing-masing channel dan tabel XIV menunjukkan nilai rata-rata hasil OSNR dari simulasi yang dilakukan. Nilai OSNR yang direkomendasikan adalah $25 \mathrm{~dB}$.

Tabel 13(a) Hasil OSNR pada Bit rate 7 Gbps

\begin{tabular}{|c|c|c|c|c|c|}
\hline \multirow{2}{*}{$\begin{array}{c}\text { Frequency } \\
(\mathrm{THz})\end{array}$} & \multicolumn{5}{|c|}{ Bit Rate 7 Gbps } \\
\cline { 2 - 6 } & 60 & 70 & 80 & 90 & 100 \\
\hline & $39.532372 \mathrm{~dB}$ & $37.7904 \mathrm{~dB}$ & $35.861142 \mathrm{~dB}$ & $33.948467 \mathrm{~dB}$ & $32.090155 \mathrm{~dB}$ \\
\hline 193.1 & $39.545434 \mathrm{~dB}$ & $37.74767 \mathrm{~dB}$ & $35.967211 \mathrm{~dB}$ & $34.011767 \mathrm{~dB}$ & $32.10521 \mathrm{~dB}$ \\
\hline 193.2 & $38.838204 \mathrm{~dB}$ & $37.34678 \mathrm{~dB}$ & $35.644881 \mathrm{~dB}$ & $33.778609 \mathrm{~dB}$ & $31.850302 \mathrm{~dB}$ \\
\hline 193.3 & $38.925897 \mathrm{~dB}$ & $37.374403 \mathrm{~dB}$ & $35.597434 \mathrm{~dB}$ & $33.816254 \mathrm{~dB}$ & $31.942811 \mathrm{~dB}$ \\
\hline 193.4 & $38.85345 \mathrm{~dB}$ & $37.31423 \mathrm{~dB}$ & $35.650653 \mathrm{~dB}$ & $33.797918 \mathrm{~dB}$ & $31.90525 \mathrm{~dB}$ \\
\hline 193.5 & $38.8847 \mathrm{~dB}$ & $37.403992 \mathrm{~dB}$ & $35.626552 \mathrm{~dB}$ & $33.84418 \mathrm{~dB}$ & $31.874554 \mathrm{~dB}$ \\
\hline 193.6 & $39.417379 \mathrm{~dB}$ & $37.741964 \mathrm{~dB}$ & $36.054581 \mathrm{~dB}$ & $34.024657 \mathrm{~dB}$ & $32.090037 \mathrm{~dB}$ \\
\hline 193.7 & $39.491183 \mathrm{~dB}$ & $37.743079 \mathrm{~dB}$ & $35.896836 \mathrm{~dB}$ & $33.94219 \mathrm{~dB}$ & $32.046459 \mathrm{~dB}$ \\
\hline 193.8 & \multicolumn{5}{|c}{}
\end{tabular}


Tabel 13(b) Hasil OSNR pada Bit rate 8 Gbps

\begin{tabular}{|c|c|c|c|c|c|}
\hline \multirow{3}{*}{$\begin{array}{l}\text { Frequency } \\
\quad(\mathrm{THz})\end{array}$} & \multicolumn{5}{|c|}{ Bit Rate 8 Gbps } \\
\hline & \multicolumn{5}{|c|}{ Panjang Fiber SMF + DCF (Km) } \\
\hline & 60 & 70 & 80 & 90 & 100 \\
\hline 193.1 & $40.072255 \mathrm{~dB}$ & $38.081122 \mathrm{~dB}$ & $36.083417 \mathrm{~dB}$ & $34.097746 \mathrm{~dB}$ & $32.115299 \mathrm{~dB}$ \\
\hline 193.2 & $40.201128 \mathrm{~dB}$ & $38.191715 \mathrm{~dB}$ & $36.013993 \mathrm{~dB}$ & $34.060347 \mathrm{~dB}$ & $32.143767 \mathrm{~dB}$ \\
\hline 193.3 & $40.102516 \mathrm{~dB}$ & $38.116014 \mathrm{~dB}$ & $36.152517 \mathrm{~dB}$ & $34.054627 \mathrm{~dB}$ & $32.119652 \mathrm{~dB}$ \\
\hline 193.4 & $40.104138 \mathrm{~dB}$ & $38.109788 \mathrm{~dB}$ & $36.096223 \mathrm{~dB}$ & $34.105071 \mathrm{~dB}$ & $32.160071 \mathrm{~dB}$ \\
\hline 193.5 & $40.061154 \mathrm{~dB}$ & $38.08105 \mathrm{~dB}$ & $36.034278 \mathrm{~dB}$ & $34.120668 \mathrm{~dB}$ & $32.105417 \mathrm{~dB}$ \\
\hline 193.6 & $40.071861 \mathrm{~dB}$ & $38.067209 \mathrm{~dB}$ & $36.140374 \mathrm{~dB}$ & $34.135449 \mathrm{~dB}$ & $31.971138 \mathrm{~dB}$ \\
\hline 193.7 & $40.058777 \mathrm{~dB}$ & $38.068643 \mathrm{~dB}$ & $36.101551 \mathrm{~dB}$ & $34.149745 \mathrm{~dB}$ & $32.100158 \mathrm{~dB}$ \\
\hline 193.8 & $40.198683 \mathrm{~dB}$ & $38.213091 \mathrm{~dB}$ & $36.089185 \mathrm{~dB}$ & $34.061972 \mathrm{~dB}$ & $32.13536 \mathrm{~dB}$ \\
\hline
\end{tabular}

Tabel 13(c) Hasil OSNR pada Bit rate 9 Gbps

\begin{tabular}{|c|c|c|c|c|c|}
\hline \multirow{2}{*}{$\begin{array}{c}\text { Frequency } \\
(\mathrm{THz})\end{array}$} & \multicolumn{5}{|c|}{ Bit Rate 9 Gbps } \\
\cline { 2 - 6 } & 60 & 70 & 80 & 90 & 100 \\
\hline 193.1 & $17.514388 \mathrm{~dB}$ & $17.555227 \mathrm{~dB}$ & $17.507774 \mathrm{~dB}$ & $17.573005 \mathrm{~dB}$ & $17.499588 \mathrm{~dB}$ \\
\hline 193.2 & $17.482 \mathrm{~dB}$ & $17.544476 \mathrm{~dB}$ & $17.650465 \mathrm{~dB}$ & $17.716469 \mathrm{~dB}$ & $17.441248 \mathrm{~dB}$ \\
\hline 193.3 & $17.532226 \mathrm{~dB}$ & $17.601069 \mathrm{~dB}$ & $17.538362 \mathrm{~dB}$ & $17.527349 \mathrm{~dB}$ & $17.618829 \mathrm{~dB}$ \\
\hline 193.4 & $14.39874 \mathrm{~dB}$ & $14.462372 \mathrm{~dB}$ & $14.534216 \mathrm{~dB}$ & $14.533432 \mathrm{~dB}$ & $14.457425 \mathrm{~dB}$ \\
\hline 193.5 & $14.308431 \mathrm{~dB}$ & $14.411707 \mathrm{~dB}$ & $14.553316 \mathrm{~dB}$ & $14.550142 \mathrm{~dB}$ & $14.376731 \mathrm{~dB}$ \\
\hline 193.6 & $17.573703 \mathrm{~dB}$ & $17.666121 \mathrm{~dB}$ & $17.54939 \mathrm{~dB}$ & $17.598408 \mathrm{~dB}$ & $17.540021 \mathrm{~dB}$ \\
\hline 193.7 & $17.584559 \mathrm{~dB}$ & $17.64482 \mathrm{~dB}$ & $17.621728 \mathrm{~dB}$ & $17.530376 \mathrm{~dB}$ & $17.634131 \mathrm{~dB}$ \\
\hline 193.8 & $17.562917 \mathrm{~dB}$ & $17.620671 \mathrm{~dB}$ & $17.621864 \mathrm{~dB}$ & $17.560873 \mathrm{~dB}$ & $17.463849 \mathrm{~dB}$ \\
\hline
\end{tabular}

Tabel 13(c) Hasil OSNR pada Bit rate $10 \mathrm{Gbps}$

\begin{tabular}{|c|c|c|c|c|c|}
\hline \multirow{2}{*}{$\begin{array}{c}\text { Frequency } \\
(\mathrm{THz})\end{array}$} & \multicolumn{5}{|c|}{ Bit Rate 10 Gbps } \\
\cline { 2 - 6 } & 60 & 70 & 80 & 90 & 100 \\
\hline & $37.399821 \mathrm{~dB}$ & $36.188289 \mathrm{~dB}$ & $34.624481 \mathrm{~dB}$ & $33.051558 \mathrm{~dB}$ & $31.336364 \mathrm{~dB}$ \\
\hline 193.1 & $37.264898 \mathrm{~dB}$ & $36.136411 \mathrm{~dB}$ & $34.711863 \mathrm{~dB}$ & $33.223063 \mathrm{~dB}$ & $31.419569 \mathrm{~dB}$ \\
\hline 193.2 & $37.27254 \mathrm{~dB}$ & $36.192899 \mathrm{~dB}$ & $34.730756 \mathrm{~dB}$ & $33.186058 \mathrm{~dB}$ & $31.442724 \mathrm{~dB}$ \\
\hline 193.3 & $35.61794 \mathrm{~dB}$ & $34.929899 \mathrm{~dB}$ & $33.843512 \mathrm{~dB}$ & $32.376388 \mathrm{~dB}$ & $31.022761 \mathrm{~dB}$ \\
\hline 193.5 & $35.303405 \mathrm{~dB}$ & $34.733076 \mathrm{~dB}$ & $33.866948 \mathrm{~dB}$ & $32.569094 \mathrm{~dB}$ & $30.997039 \mathrm{~dB}$ \\
\hline 193.6 & $37.224067 \mathrm{~dB}$ & $36.27269 \mathrm{~dB}$ & $34.804165 \mathrm{~dB}$ & $33.126306 \mathrm{~dB}$ & $31.397016 \mathrm{~dB}$ \\
\hline 193.7 & $37.180027 \mathrm{~dB}$ & $36.15647 \mathrm{~dB}$ & $34.68253 \mathrm{~dB}$ & $33.137468 \mathrm{~dB}$ & $31.488035 \mathrm{~dB}$ \\
\hline 193.8 & $37.096036 \mathrm{~dB}$ & $35.96347 \mathrm{~dB}$ & $34.740733 \mathrm{~dB}$ & $33.128168 \mathrm{~dB}$ & $31.413474 \mathrm{~dB}$ \\
\hline
\end{tabular}

Tabel 14 Hasil rata-rata $O S N R$

\begin{tabular}{|c|c|c|c|c|c|c|}
\hline Jumlah & Bit Rate & \multicolumn{5}{|c|}{ Panjang Fiber SMF + DCF (Km) } \\
\cline { 2 - 7 } Kanal & $($ Gbps $)$ & 60 & 70 & 80 & 90 & 100 \\
\hline \multirow{4}{*}{8} & 7 & $39.1860774 \mathrm{~dB}$ & $37.557815 \mathrm{~dB}$ & $35.787411 \mathrm{~dB}$ & $33.8955053 \mathrm{~dB}$ & $31.9880973 \mathrm{~dB}$ \\
\cline { 2 - 7 } & 8 & $40.108814 \mathrm{~dB}$ & $38.116079 \mathrm{~dB}$ & $36.088942 \mathrm{~dB}$ & $34.0982031 \mathrm{~dB}$ & $32.1063578 \mathrm{~dB}$ \\
\cline { 2 - 7 } & 9 & $16.7446205 \mathrm{~dB}$ & $16.8133079 \mathrm{~dB}$ & $16.822139 \mathrm{~dB}$ & $16.8237568 \mathrm{~dB}$ & $16.7539778 \mathrm{~dB}$ \\
\cline { 2 - 7 } & 10 & $36.7948418 \mathrm{~dB}$ & $35.8216505 \mathrm{~dB}$ & $34.500624 \mathrm{~dB}$ & $32.9747629 \mathrm{~dB}$ & $31.3146228 \mathrm{~dB}$ \\
\hline
\end{tabular}

Pada gambar 4 menunjukkan nilai Min BER yang dihasilkan dengan ragam variasi Bit rate dan ragam variasi panjang fiber SMF. Min BER dianggap baik apabila nilainya semakin kecil. Pada penelitian ini minimum threshold yang gunakan untuk menilai performance Min BER adalah $10^{-12}$ 


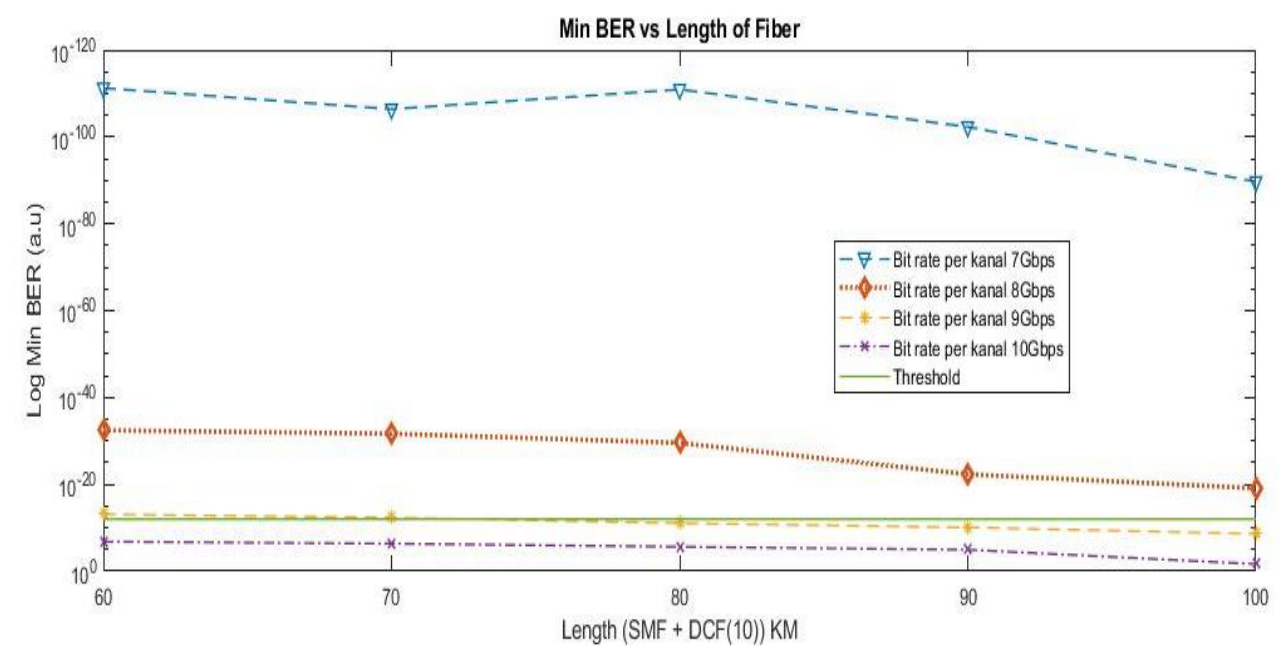

Gambar 4. Grafik Log Min BER sistem optik DWDM dengan penguat EDFA dengan variasi Bit rate \& panjang fiber SMF

Hasil penelitian menunjukkan bahwa sistem optik DWDM dengan penguat EDFA dengan variasi Bit rate $7 \mathrm{Gbps}, 8 \mathrm{Gbps}, 9 \mathrm{Gbps}, 10 \mathrm{Gbps}$ dan variasi panjang fiber SMF $50 \mathrm{~km}, 60 \mathrm{~km}, 70 \mathrm{~km}, 80 \mathrm{~km}, 90 \mathrm{~km}$ dengan panjang fiber DCF konstan $10 \mathrm{~km}$. Dapat dilihat bahwa nilai BER yang belum memenuhi standar adalah Bit rate 9 Gbps pada panjang fiber $90 \mathrm{~km}$ dengan nilai BER yang diperoleh adalah 8.1949E-11. Hal ini juga berlaku pada Bit rate $10 \mathrm{Gbps}$ dengan variasi panjang fiber $60 \mathrm{~km}, 70 \mathrm{~km}, 80 \mathrm{~km}, 90 \mathrm{~km}$ dan $100 \mathrm{~km}$ masing-masing BER yaitu $10^{-7}, 10^{-6}, 10^{-5}$ dan 0.01243543. Akan tetapi untuk Bit rate 7 Gbps dan 8 Gbps dengan variasi panjang fiber $60 \mathrm{~km}, 70 \mathrm{~km}, 80 \mathrm{~km}, 90 \mathrm{~km}$ dan $100 \mathrm{~km}$ telah memenuhi standar nilai minimum BER.

Berdasarkan gambar 5 menunjukkan nilai $Q$-Factor yang dihasilkan dengan ragam variasi Bit rate dan ragam variasi panjang fiber SMF serta panjang fiber DCF yang konstan. Semakin besar nilai $Q$-Factor, semakin baik pula kinerja sistem. Pada penelitian ini standar threshold untuk Q-Factor adalah bernilai 7. Hasil penelitian menunjukkan bahwa sistem optik DWDM dengan penguat EDFA dengan variasi Bit rate 7 Gbps, 8 Gbps, 9 Gbps, 10 Gbps dan variasi panjang fiber SMF 50 km, 60 km, 70 km, 80 km, 90 km dan panjang fiber DCF konstan $10 \mathrm{~km}$. Dapat dilihat bahwa nilai Q-Factor yang belum memenuhi standar threshold adalah Bit rate 9 Gbps pada panjang fiber $80 \mathrm{~km}$ dengan nilai $Q$-Factor yang diperoleh adalah 6.79133. Hal ini juga berlaku pada Bit rate 10 Gbps dengan variasi panjang fiber $60 \mathrm{~km}, 70 \mathrm{~km}, 80 \mathrm{~km}$, $90 \mathrm{~km}$ dan $100 \mathrm{~km}$ masing-masing nilai $Q$-Factor tidak memenuhi standar minimal $Q$-Factor. Sedangkan pada variasi Bit rate 7 Gbps dan 8 Gbps dengan variasi panjang fiber telah memenuhi standar Q-Factor minimum. 


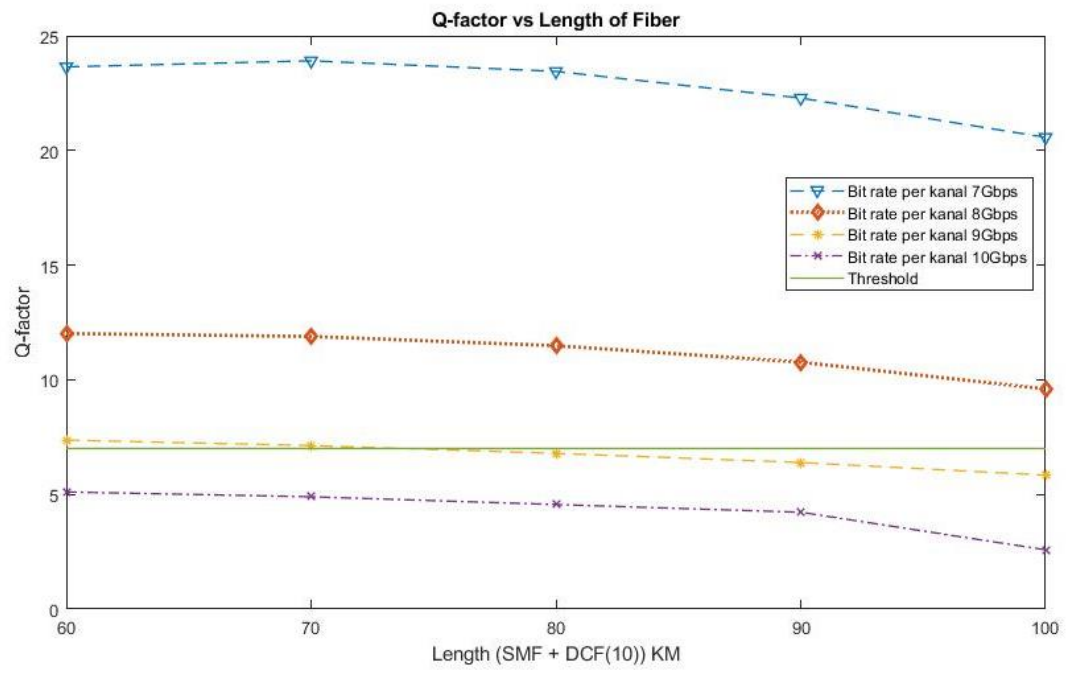

Gambar 5. Grafik Q-Factor sistem optik DWDM dengan penguat EDFA dengan variasi Bit rate \& panjang fiber SMF

Berdasarkan gambar 6 berikut menunjukkan bahwa hasil simulasi sistem optik DWDM dengan penguat EDFA dengan variasi Bit rate $7 \mathrm{Gbps}$ dan variasi pajang fiber optik sepanjang $100 \mathrm{~km}$ dapat dilihat bahwa penelitian yang telah dilakukan sesuai dengan standar yang ditentukan dengan performa kerja BER yang diperoleh secara rata-rata dari 8 channel sangat baik yaitu 2.1352E-90 dengan nilai $Q$ Factor sebesar 20.5732875 .
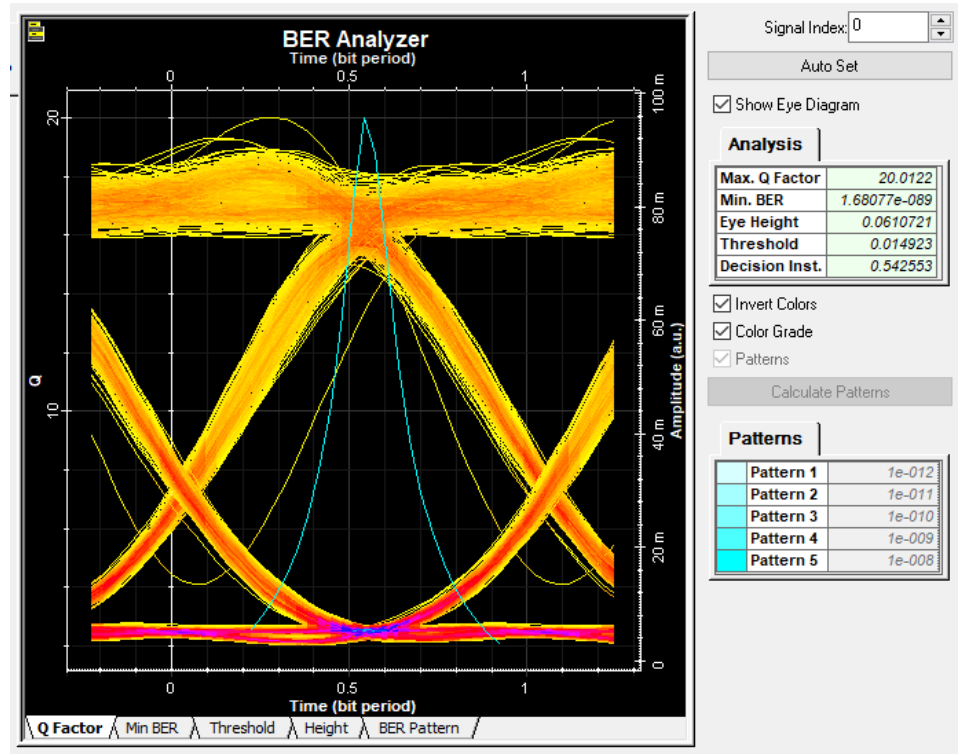

Gambar 6. Eye Diagram Bit rate 7 Gbps jarak $100 \mathrm{~km}$

Berdasarkan gambar 7 menunjukkan nilai SNR yang dihasilkan dengan ragam variasi Bit rate dan ragam panjang fiber SMF serta panjang fiber DCF yang konstan. SNR dianggap paling baik jika nilai SNR lebih dari $25 \mathrm{~dB}$ 


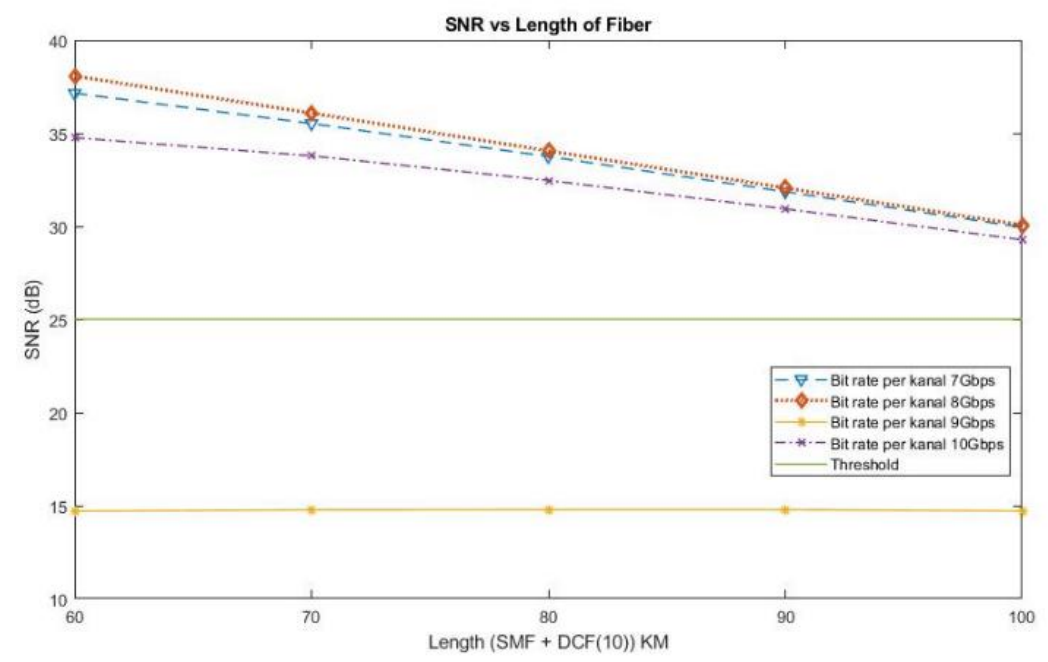

Gambar 7. Grafik SNR DWDM dengan penguat EDFA

dengan variasi Bit rate \& variasi panjang fiber SMF

Hasil penelitian menunjukkan bahwa sistem optik DWDM dengan penguat EDFA dengan variasi Bit rate $7 \mathrm{Gbps}, 8 \mathrm{Gbps}, 9 \mathrm{Gbps}, 10 \mathrm{Gbps}$ dan variasi panjang fiber SMF $50 \mathrm{~km}, 60 \mathrm{~km}, 70 \mathrm{~km}, 80 \mathrm{~km}, 90 \mathrm{~km}$ dan panjang fiber DCF konstan $10 \mathrm{~km}$. Dari gambar 4.4 dapat dilihat bahwa nilai SNR yang tidak memenuhi standar adalah Bit rate 9 Gbps dengan variasi panjang fiber $60 \mathrm{~km}, 70 \mathrm{~km}, 80 \mathrm{~km}, 90$ dan 100 $\mathrm{km}$ dengan nilai SNR masing-masing kurang dari $25 \mathrm{~dB}$. Hal ini disebab oleh sistem DWDM yang memiliki banyak panjang gelombang atau frekuensi yang digunakan. Disisi lain, komponen dalam sistem komunikasi mulai transmitter hingga receiver memiliki rentang kerja yang berbeda hingga memiliki respon berbeda terhadap panjang gelombang tertentu sehingga menyebabkan nilai SNR kurang dari 25 dB. Akan tetapi untuk variasi Bit rate $7 \mathrm{Gbps}, 8 \mathrm{Gbps}$ dan $10 \mathrm{Gbps}$ dengan variasi panjang fiber $60 \mathrm{~km}$, $70 \mathrm{~km}, 80 \mathrm{~km}, 90$ dan $100 \mathrm{~km}$ telah memenuhi standar rekomendasi SNR yaitu lebih dari $25 \mathrm{~dB}$.

Berdasarkan gambar 8 menunjukkan nilai OSNR yang dihasilkan dengan ragam variasi Bit rate dan ragam panjang fiber SMF serta panjang fiber DCF yang konstan. OSNR dianggap paling baik jika nilainya lebih dari $25 \mathrm{~dB}$.

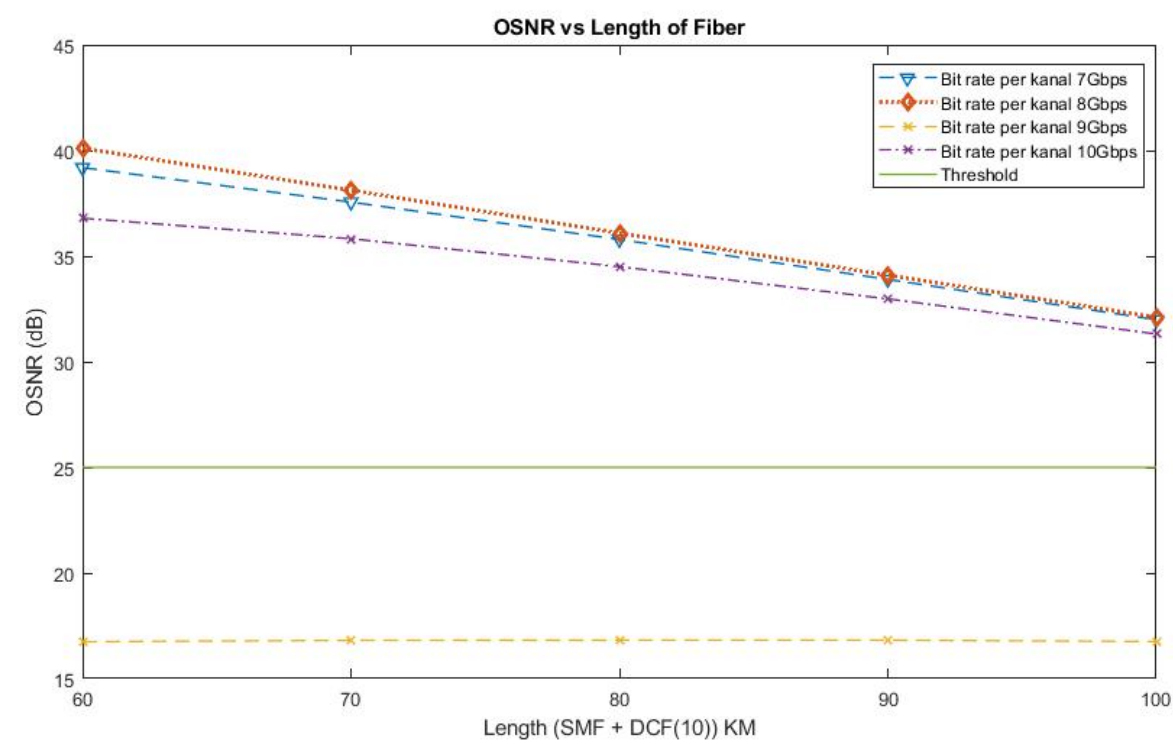

Gambar 8 Grafik OSNR DWDM dengan penguat EDFA dengan variasi Bit rate \& variasi panjang fiber SMF 
Hasil penelitian menunjukkan bahwa sistem optik DWDM dengan penguat EDFA dengan variasi Bit rate 7 Gbps, 8 Gbps, 9 Gbps, 10 Gbps dan variasi panjang fiber SMF 50 km, 60 km, 70 km, 80 km, 90 $\mathrm{km}$ dan panjang fiber DCF konstan $10 \mathrm{~km}$. Dari gambar 4.5 dapat dilihat bahwa nilai OSNR yang tidak memenuhi standar adalah Bit rate 9 Gbps dengan variasi panjang fiber $60 \mathrm{~km}, 70 \mathrm{~km}, 80 \mathrm{~km}, 90$ dan 100 $\mathrm{km}$ dengan nilai SNR masing-masing kurang dari $25 \mathrm{~dB}$. Akan tetapi untuk variasi Bit rate 7 Gbps, 8 Gbps dan 10 Gbps dengan variasi panjang fiber $60 \mathrm{~km}, 70 \mathrm{~km}, 80 \mathrm{~km}, 90$ dan $100 \mathrm{~km}$ telah memenuhi standar rekomendasi SNR yaitu lebih dari $25 \mathrm{~dB}$.

Pada gambar 9(a)(b) menunjukkan nilai perubahan Optical Spectrum yang dihasilkan sebelum EDFA dan setelah EDFA.

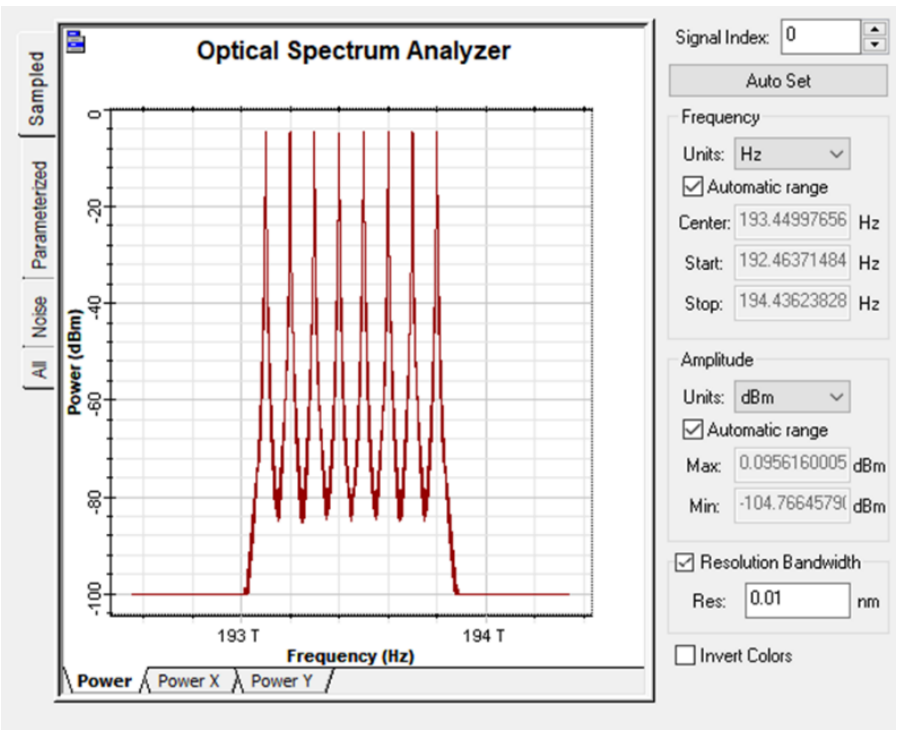

Gambar 9(a) Grafik Optical Spectrum sebelum penguat EDFA

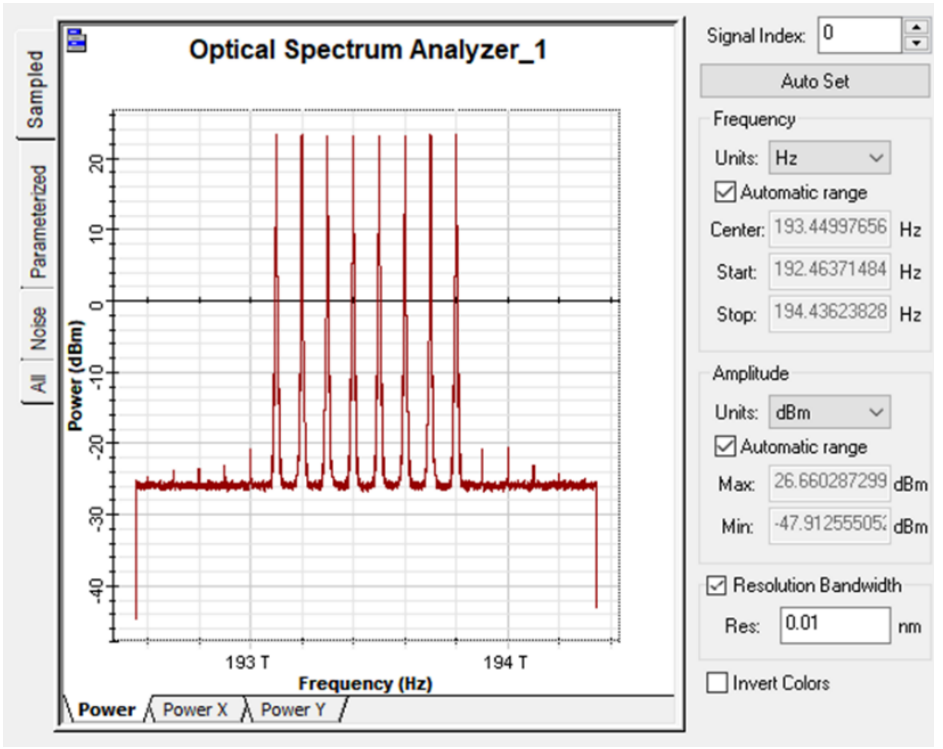

Gambar 9(b) Grafik Optical Spectrum setelah penguat EDFA

Hasil penelitian menunjukkan bahwa sistem optik DWDM dengan penguat EDFA dengan variasi Bit rate $7 \mathrm{Gbps}, 8 \mathrm{Gbps}, 9 \mathrm{Gbps}, 10 \mathrm{Gbps}$ dan variasi panjang fiber SMF $50 \mathrm{~km}, 60 \mathrm{~km}, 70 \mathrm{~km}, 80 \mathrm{~km}, 90$ $\mathrm{km}$ dan panjang fiber DCF konstan $10 \mathrm{~km}$. Telah dengan standar yang ditentukan serta memenuhi 
ekspektasi racangan karena Power input laser dari masing-masing channel adalah $0 \mathrm{dBm}$ mengalami penguatan sebesar $26.660 \mathrm{dBm}$ setelah pengunaan penguat EDFA. Hal ini dapat dilihat pada gambar 4.6(a) memiliki Max Power Spectrum masing-masing channel yakni $0.0956160005 \mathrm{dBm}$ sedangkan pada gambar 4.6(b) memiliki Max Power Spectrum masing-masing channel yakni $26.660 \mathrm{dBm}$.

\section{KESIMPULAN}

Penggunaan penguat EDFA sangat berpengaruh pada kelayakan BER dan Q-Factor khususnya pada Bit rate 7 Gbps dan 8 Gbps dengan maksimal panjang fiber $100 \mathrm{~km}$. Pada Bit rate 9 Gbps dan 10 Gbps untuk semua variasi panjang fiber optik terdapat nilai BER dan Q-Factor yang tidak memenuhi standar kelayakan. Dari semua skema penelitian terdapat nilai SNR dan OSNR yang tidak sesuai standar pada Bit rate 9 Gbps untuk semua variasi panjang fiber. Hal ini disebabkan oleh karakteristik dari DWDM yang memiliki banyak frekuensi yang digunakan serta komponen pada transmitter dan receiver yang memiliki respon yang berbeda pada rentang frekuensi dan Bit rate tertentu. Hasil pengujian ini juga membuktikan bahwa semakin panjang fiber optik maka nilai BER dan Q-Factor akan semakin berkurang.

\section{REFERENSI}

[1] Keiser, Gerard, 1991, "Optical Fiber Communication 3rd Edition”, Mc Graw-Hill Inc.

[2] Dewiani $D^{1}$, Andani $A^{2}$, Fiqri $\mathrm{H}^{3}$, Dhanang B $\mathrm{B}^{4}, 2017$, "Analisis Penguat EDFA dan SOA pada Sistem Transmisi DWDM dengan Optisystem 14,” Universitas Hasanudin, Jurnal, Gowa, Sulawesi Selatan, Indonesia.

[3] Sri Danaryani ${ }^{1}$, Syamsul El Yumin"2, Iwan Krisnadi ${ }^{3}$, 2015, "Studi Perancangan Jaringan Komunikasi Serat Optik Dwdm L Band dengan Penguat Optikal EDFA,” Politeknik Negeri Jakarta, Jurnal, Jakarta, Indonesia.

[4] Jovi Brema Barus ${ }^{1}$, Fauza Khair ${ }^{2}$, Eko Fajar C³ 2018 "Analisis Pengaruh Penguat Edfa (Erbium Doped Fiber Amplifier) Pada Sistem Radio Over Fiber (Rof) dengan Mekanisme Optical Interleaver," ITT Purwokerto, Jurnal, Purwokerto, Jawa Tengah, Indonesia.

[5] Lazuardi Ramadeanto ${ }^{1}$, Akhmad Hambali², Brian Pramukti ${ }^{3}, 2018$, "PERFORMANSI EDFA DI SETIAP BIT RATE YANG DIKIRIMKAN DARI TRANSMITTER KE RECEIVER PADA JARAK 50 KM PADA SISTEM,” Universitas Telkom, Jurnal, Bandung, Jawa Barat, Indonesia.

[6] “Konsep Dasar Serat Optik dan Dense Wavelength Division Multiplexing”Universitas Sumatera Utara 